\title{
A maldade dos homens se multiplicou sobre a terra: sobre o fenômeno da violência na bíblia
}

\author{
The wickedness of men multiplied on earth: on \\ the phenomenon of violence in the bible
}

\author{
Haroldo Reimer ${ }^{[a]}$, Ivoni Richter Reimer ${ }^{[b]^{*}}$ \\ [a] Universidade Estadual de Goiás (UEG), Anápolis, G0, Brasil \\ [b] Pontifícia Universidade Católica de Goiás (PUC Goiás), Goiânia, G0, Brasil
}

\section{Resumo}

0 artigo procura descortinar como a questão da violência é tratada em textos da Bíblia. Parte-se da constatação de que não há na Bíblia um termo específico para designar o que hodiernamente chamamos de violência, abarcando desde a violência física até a violência psicológica/simbólica. Com base em pesquisa bibliográfica, o artigo ressalta que a violência é um fenômeno que acompanha a história dos humanos na sua relação com o ambiente e com outras pessoas, sendo sua realização sempre uma possibilidade latente. Busca-se mostrar como os autores dos textos bíblicos se utilizam da linguagem comum, com todas as possibilidades e expressões de violência, para expressar

\footnotetext{
*HR: Doutor em Teologia, e-mail: haroldo.reimer@gmail.com

IRR: Doutora em Filosofia e Teologia, e-mail: ivonirr@gmail.com
} 
conteúdos, em parte, em conformidade com estruturas culturais e de poder e violência e, em parte, apresentando projeções contraculturais. Indica-se também que, apesar do uso intensivo de linguagem com semântica da violência, textos bíblicos também projetam formas de superação da violência.

Palavras-chave: Bíblia. Violência. Religião. Relações de Poder.

\section{Abstract}

This article intends to find out how the issue of violence is treated in biblical texts. It starts by noting that the Bible has no specific word to designate what we use do call violence, from physical to psychological/symbolic violence. Based on bibliographic research, the article points out that violence is a phenomenon which accompanies the history of humankind in its relation with the environment and other people, its accomplishment being always a latent possibility. It tries to show how the authors of biblical texts use common language, with all possibilities and expressions of violence, to express contents partly in accordance with cultural structures of power and violence, and partly showing counter-cultural projections. It is also points out that, even intensively using the semantics of violence, Biblical texts also project ways to overcome violence.

Keywords: Bible. Violence. Religion. Power relations.

\section{Introdução}

O propósito do artigo é perscrutar, na Bíblia, se e como a violência é um fenômeno que acompanha o desenvolvimento e a história da humanidade. A metodologia bibliográfica toma os textos bíblicos como fonte primária, e utiliza referenciais teóricos da análise de textos bíblicos, exegese e hermenêutica, na interface com ciências que contribuem com a pesquisa dos contextos históricos, sociais e culturais, nos quais os textos foram sendo formados, transmitidos e recepcionados. No processo de buscar e encontrar, apresentamos dados e reflexões sobre o fenômeno 
da violência humana, na forma como a questão é apresentada em textos sagrados da tradição judaico-cristã. Tratam-se de textos do Antigo e Novo Testamentos, este último constituindo uma parcela própria da releitura dos textos anteriores da tradição judaica, feita pelas comunidades cristãs e seus atores e atrizes principais.

Com isto, queremos contribuir com pesquisas acadêmico-científicas, com formação de lideranças teológicas e pastorais, que atuam em centros de formação, também em nível eclesial e em movimentos sociais.

\section{Percepções obtidas na pesquisa e na vida}

Neste estudo, observamos que o uso de força "bruta" está insculpida no modo de relação dos humanos com o ambiente, em especial com a fauna e a flora, desde as origens mais remotas. Contudo e aqui especificamente, destacamos que esta força permeia a relação com os outros humanos, declinando-se também em termos de relações de gênero e relações hierárquicas de poder. Esse modus operandi com o uso de força física bruta no cotidiano da vida acompanha a evolução e o desenvolvimento dos humanos, marcando o jeito de ser das pessoas ao longo do tempo, apresentando-se como potencialidade sempre latente no inconsciente, tornando-as um poço de ambiguidade e contradições, podendo, a qualquer momento, romper os mantos de civilidade adquiridos por processos educativos.

Junto com isso, a história da humanidade também é acompanhada por multiformes processos sociais, no sentido civilizatório de dominar a violência e/ou a maldade, por meio de formas socialmente produzidas e coletivamente sustentadas. Tabus, interdições, normas e leis fazem parte deste processo que busca inserir os humanos na vida em coletividade, buscando um nível civilizatório mais elevado; contudo, também este conjunto de normas pode conter em si complexidades que acarretem prejuízos para as partes mais frágeis e afetadas na vivência da violência ${ }^{1}$. Processos coercitivos estão constantemente inseridos nesta marcha

1 A este respeito, ver Detienne (2011), que trata de questões legais e jurídicas de textos normativos acerca de “relações sexuais ilícitas”, em Dt 22,22-29. 
civilizatória do ser humano, convertendo-se também em formas educativas com o objetivo de moldar a pessoa a conviver com as outras e em comunidade dentro de padrões estabelecidos coletivamente, e socialmente aceitos. A não adesão a tais formas educativas e civilizatórias carrega consigo sempre a possibilidade do recurso à coerção, a exemplo das leis e da história penal, distintas em contextos diferentes, mas convergentes no mesmo propósito da pacificação social. Os processos educativos e a constante ameaça de uso de formas coercitivas, contudo, não são capazes de tirar a marca da violência inscrita no DNA dos humanos. A violência aflora em situações muito distintas, desde formas de aplicação de força física bruta até a violência psicológico-simbólica contra pessoas, (des)iguais, especialmente contra mulheres e crianças, legalmente consideradas os elos mais frágeis na cadeia de relação dos humanos. Com um incremento civilizatório, contemporaneamente, também as formas de violência contra o ambiente são incluídas no caleidoscópio das formas de violência.

$\mathrm{O}$ uso da violência também faz parte da história das religiões. Aqui cabe lembrar que quando tratamos de "religião", referimo-nos a um sistema relativamente organizado de símbolos, gestualidades, textualidades e estruturas de hierarquia e de organização social (CROATTO, 2001). Cada religião ou expressão religiosa procura apresentar formas de acesso a um sagrado. Nas religiões monoteístas, este sagrado é apresentado como Deus criador, ao qual é atribuído, gradativamente, o papel de divindade única. As religiões, enquanto parte da expressão cultural, projetam e estabelecem formas de domínio e superação da violência, neste sentido contribuindo com o processo socioeducativo das pessoas. Ao fazê-lo, porém, também recorrem a formas coercitivas de diferentes intensidades. A implantação do monoteísmo, no caso do Judaísmo, Cristianismo e Islamismo, também constitui um processo de violência simbólica, acompanhada não raras vezes de violência física.

\section{Violência em textos sagrados, em especial o caso da Bíblia}

Os traços marcantes da violência na história dos humanos também são percebidos como fenômeno por quem formulou os textos sagrados, e ali os refletiu. De forma geral, os textos sagrados também contêm linguagem 
de violência, sendo que esta é manejada de formas distintas, desde a mera descrição até a justificação ou interdição de violência em suas múltiplas formas. Dizer que o fenômeno da violência é objeto de percepção pelos textos sagrados significa pressupor e dizer que os textos sagrados são produções humanas que, desde os momentos hierofânicos, passaram por complexos processos de seleção, depuração e edição até chegar a formas consideradas canônicas. Quando textos sagrados se tornam canônicos, determinada coletividade assume que tais textos se tornam compromissivos para estas comunidades, havendo até o apelo de universalidade dos textos, como é o caso da Bíblia ou mesmo do Corão.

A violência acompanha e perpassa as páginas da Bíblia. Do mesmo modo o fazem as tentativas ou propostas de sua superação ou as estratégias de pacificação ou construção de paz. Biblicamente, tomamos a experiência de escravidão, feita pelo povo hebreu no Egito, e a experiência da cruz, feita por Jesus, por marcos referenciais para observação do fenômeno violência. Consideramos que tais experiências foram/são vivenciadas por milhares de outras pessoas e são, aqui, portanto, representativas também em suas formas de superação.

Em termos semânticos, na Bíblia não existe um termo específico para o que chamamos hodiernamente de violência. Mas podemos trabalhar com o dado de que o que em termos bíblicos se designa, por múltiplos termos, de ações violentas abarca o que nós hoje entendemos como violência física, incluindo a psicológica e simbólica. Os conteúdos sempre são expressos por diversos substantivos e verbos. Aqui, não poderemos tratar de todos eles, mas destacamos alguns.

No Antigo Testamento (AT) é bastante comum o uso de termos com significado de "maldade" ou "o mal" (em hebraico ra'ah) para se referir ao que é violência. "Fazer o mal", aos olhos de Deus ou diante das pessoas, é uma expressão recorrente em textos bíblicos. Neste caso, a ação realizada recebe uma avaliação negativa decorrente de determinado código éticojá estabelecido ou em processo de afirmação. Na perspectiva monoteísta do AT, é recorrente, dentro do bloco designado de Livros Históricos ou Obra Historiográfica Deuteronomista (Deuteronômio até 2Reis), designar a adoração de outros deuses, chamado de idolatria, como "fazer o mal" aos olhos de Deus. 
É importante observar também os cognatos semânticos para entender o fenômeno em questão da violência. Assim, o poder ou o exercício de poder muitas vezes está vinculado com a violência ou com a prática da maldade. A terminologia relativa ao exercício de violência se aplica tanto a pessoas quanto a Deus. Desta forma, o termo $E l$, que significa força ou violência, é usado para descrever a própria Divindade hebraica em sua potência máxima (por exemplo Gn 32,29; Mq 2,1). Um dos nomes de Deus - Elohim - é a forma extensa desta indicação de potência. Assim, Deus é entendido como afirmação de força e poder concentrados. Termos que nominam partes do corpo como a mão (em hebraico yad) e a palma da mão (kaf) também são utilizados para denotar violência. Estar sob a mão de alguém ou entregar alguém à mão de outrem são expressões que indicam o exercício de poder com violência na relação com o outro (ex. Jz 6,13; Jr 12,7). Na história da iconografia hebraica, o desenho da mão de Deus era entendido como elemento metafórico para o próprio Deus.

Vários verbos em hebraico estão intrinsicamente relacionados com o exercício de ações violentas: o verbo hamas significa "oprimir" "cometer injustiça” ou "cometer maldade" (Jr 22,3; Ez 22,26; Sf 3,4); o substantivo homônimo indica também para o fenômeno da opressão com uso de violência (Gn 6,11; Ex 23,1); rasah significa "assassinar" ou "ser injusto ou culpado (2 Sm 22,22; Jó 9,29; 10,7.15; Ex 22,8), sendo que o substantivo resha significa "maldade" com uso de violência (Dt 9,27) ou o "maldoso" (Is 3,$11 ; \mathrm{Hb} 1,13)$; o verbo nakah implica em "abater algo ou alguém" (Gn 4,15; Ex 2,11; etc.); alguns verbos têm sentido mais ambivalente. $O$ verbo ashaq remete mais diretamente para o sentido de "oprimir" (Is 53,7; Ex 1,11), radah, para "dominar" (Is 14,2); o verbo anah implica o sentido de "rebaixar, humilhar", podendo implicar também o sentido de "estuprar" (Gn 34,2; 2 Sm 13,12.14; Jz 19,24; Lm 5,11). O substantivo ani, derivado do verbo anah, expressa o sentido de "oprimido" ou "pessoa oprimida" em sentido lato. O verbo ramas, que significa literalmente "pisar, pisotear", é usado em relação a pessoas (2Rs 7,17.20); o verbo baqah é usado para dividir lenha ao meio (Gn 22,3), mas também se aplica em relação à violência contra mulheres grávidas (Am 1,13), podendo ser traduzido por "partir ao meio".

No Novo Testamento (NT) também há um uso diversificado de expressões que se referem ao fenômeno e ao exercício de violência. $\mathrm{O}$ 
termo grego específico para a palavra "violência", como a conhecemos hoje, não aparece no NT; como no AT, há também aqui uma gama de termos que se referem a ações violentas. Destacamos algumas situações. O termo grego bía caracteriza a força física e, especificamente em situações violentas, de guardas que usam desta força em prisões e tumultos (At 5,26; 21,35; 24,7); mas também o mar (At 27,41) e o céu (At 2,2) fazem sentir esta força "bruta", em caso de temporais. O verbo derivado biádzesthai consta duas vezes no NT: em Mt 11,12 e em Lc 16,16, quando Jesus ensina acerca do Reino dos Céus: "desde os dias de João Batista até agora, o Reino dos Céus é feito com força e homens violentos o tomam à força (harpádzo)", indicando para grupos de renovação que se utilizam da força para transformar as condições de vida. Um termo sinônimo para tais ações violentas é íschyros/ischýs "forte": Em Mt 12,29 (paralelo em Mc 3,27; Lc 11,21-22), que apresenta o imaginário da vitória de Jesus sobre o mal, numa referência a "um forte" que é vencido pelo "mais forte". Esta imagem é tomada da tradição (Is 49,24-25) que trata do opositor de Deus (LUZ, 1985, p. 261), e agrega a experiência dos assaltos violentos a casas de pessoas, no contexto do Novo Testamento. Partindo de tais tradições e experiências, também Ap 12,7-8 as reinstala para descrever o contexto da guerra (pólemos) do arcanjo Miguel e do dragão, no céu; o dragão não foi "forte" suficiente, e perdeu a luta. O uso desta "força bruta" sempre implica em alguma forma de violência.

Significativos para uma visão panorâmica destas formas são os termos que refletem realidades violentas no Sermão Profético proferido por Jesus, em seu caminho rumo à Paixão (Mt 24,1-28; Mc 13; Lc 21). Por isto, aqui o tomamos como elucidativo. Nele aparecem expressões de violências múltiplas conhecidas: guerras (pólemoi) entre povos e nações, fomes (límoi), epidemias (lóimoi), catástrofes naturais/terremotos (seismói), que são considerados sinais do início das "dores de parto" (odínoi)2: tribulações (thlípsis), perseguições religiosas e políticas (diogmói) e matança (apoktéino), ódio (miséo) e iniquidade (anomía), mentira e falsidade de toda espécie, incluindo corrupção (pseudos), "abutres" à

2 Acerca da imagem de “dores do parto" para elaboração da esperança escatológico-apocalíptica, ver Richter Reimer (2000). 
espreita (aetói). Trata-se da experiência de violências, presentes na história e na memória de pessoas e comunidades no contexto político, social e religioso do movimento de Jesus, de sua morte e dos esforços dedicados à reconstrução deste movimento na forma de organização de igrejas. A denúncia se dirige às autoridades políticas e religiosas, que se tornaram cruciais na culminação da Guerra Judaica, e indica também para os crescentes conflitos com o grupo sobrevivente de fariseus que igualmente se reorganizava para sobreviver à grande tragédia, na forma do incipiente judaísmo rabínico heterogêneo (STEGEMANN, 2012, p. 2931; HORSLEY, 2004). Estas experiências são memoradas para chamar à vigilância e para (re)construir um imaginário escatológico de esperança e perseverança: superação de todos estes males, salvação (Mt 24,13.31)!

O exercício de poder e autoridade, na forma de dominação e opressão, igualmente é expressa e reconhecida como causa de violência e sofrimento. No ensino de Jesus aos discípulos(as) acerca da gratuidade e significado inversor da diaconia, colocando-a também como modelo de governabilidade, consta uma avaliação negativa do modo de governar, criticado por Jesus em forma de oposição: "Vocês sabem: os que são considerados governadores dos povos os tem sob domínio senhorial (katakyrieúousin) e os maiorais deles usam seu poder contra eles [os povos] (katexousiádsosin). Mas entre vós não é assim [...]" (Mc 10,42-43). O termo exousía é amplamente utilizado em todos os gêneros literários do NT, no sentido de domínio e autoridade sobre pessoas, coisas e regiões/povos, e o uso do verbo exousiádzo indica para a possibilidade e/ou realidade de perder a liberdade por parte de quem sofre o domínio (BROER, 1992, p. 30-31). É nesse sentido que o verbo é utilizado em Lc 22,25, ou seja, "dominadores" que, para minimizar os sofrimentos, colocam-se como "benfeitores" por meio de doações, o que faz lembrar o antigo slogan romano "pão e circo". Por isto mesmo, é importante perceber que apenas dois textos utilizam o termo como katexousiádzo "usar o poder contra"/"oprimir" (Mc 10,42; Mt 22,25), aqui em questão como expressão de violência, contrapondo ao poder dos poderosos o poder diaconal de Jesus.

Todas estas e outras formas de violência estão exemplarmente expressas na morte de cruz, sofrida por Jesus e milhares de outras pessoas 
sob o regime imperial romano. Senão, vejamos ${ }^{3}$ : delação, traição, solidão e abandono, entrega de Jesus a soldados, inquirição, julgamento, acusação e escárnio do povo, torturas, deboche e zombaria, exposição pública em vários lugares, culminando na cruz, com sua morte. Hodiernamente, esta trilha de paixão e morte de Jesus corresponderia a todas as formas de violência (SINGH, 2005), inclusive a econômica, representada pelas moedas e pelo "leilão" das vestes. A violência ideológico-política também aparece nas cenas de saudação maliciosa "Salve, rei dos judeus" (Mc 15,18; Mt 27,29; Jo 19,3) e na direta acusação de ineficácia religiosa "Salvou os outros [...] Desce da cruz" (Mc 15,29-32; Lc 23,35-37; Mt 27,40-44). Com isto, também a teologia e a práxis libertadora de Jesus foram radicalmente questionadas pela e na cruz. Está é sinal da realidade da condenação por pena de morte para pessoas transgressoras do "jeito de viver romano". Além dos crimes comuns, tais pessoas eram acusadas de atentar contra a ideologia/religião do império, ameaçando a pax romana (WENGST, 1991; HORSLEY, 2004).

Estes aspectos ideológicos encontram-se no AT e no NT, que afirmam Deus como autoridade maior, recorrendo também ao uso de representações $\mathrm{Bem} / \mathrm{Mal}$ que expressam realidades violentas transcendentes as quais se presentificam entre humanos, numa eterna batalha em/entre religiões monoteístas, nas quais este Deus sai vitorioso. Assim, Mateus, reproduzindo sua herança de textos sagrados, utiliza muito o termo ponerós "mal" como representação do "Maligno", opositor de Deus (5,37; 13,19.38). No nível das relações humanas, este "Maligno" corresponde ao "maligno/mau/perverso" humano e suas correspondentes ações (5,39.45; 6,13; 13,49; 18,32). Assim também existe o "caminho do Maligno/Maldição" $(7,13)$ como consequência e fruto $(7,17)$, sendo que o Mal também toma conta do ser, cujas ações são/serão más (7,4; 12,34.39; 15,19, analogamente a Satanás, em At 5,3 (RICHTER REIMER, 2011). Diferente, Lucas não utiliza este termo para representar o "Maligno", mas apenas para caracterizar pessoas e suas ações (3,19: Herodes praticou muitos males; 3,22.35: pessoas consideradas más). De forma semelhante, Marcos utiliza o termo ponerós ("mal") apenas em 7,23, no plural, para apresentar uma série de "coisas más" que também aparecem

3 Tomamos por base a narrativa de Mc 14-16; Mt 26-27; Lc 22-23; Jo 13,21-30; 18-19. Aqui não é possível realizar uma exegese das questões, o que está sendo feito para outra publicação. 
nos "catálogos de vícios": loucura, soberba, blasfêmia, inveja, lascívia, dolo, malícias, avareza, adultério, prostituição, furtos, homicídios (7,21-22; ver $\mathrm{Cl}$ 3,5-17). Este uso diferenciado se explica pelo fato de Mateus ter um acervo de fidelidade mais próximo a heranças judaicas.

Em termos de nomenclatura, Paulo partilha destas tradições ancestrais em alguns momentos, em especial, em $\mathrm{Rm}$ 12,9.21, seguindo a máxima do amor/Bem para superar o Mal e suas manifestações (ver também 1Ts 5,22; 1 Co 5,13; Gl 1,4). Contudo, ao invés de seguir a trilha do Bem/Mal, ele construiu sua teologia muito mais a partir da concepção de pecado (hamartía) como distanciamento da vontade de Deus, o que igualmente resulta numa série de violências. Assim, com a afirmação de que, vivendo sob o sistema dominador do pecado, não há "um justo sequer" (Rm 3,9-18), ele relê tradições sapienciais e proféticas que articulam a realidade e o imaginário representativo de Bem/Mal que se manifesta em justiça/injustiça (GÜNTHER, 2000, p. 1601-02), (Sl 10,7 - boca cheia de maldição e amargura; Is 59,7; Pv 1,16 — pés velozes para derramar sangue; em seus caminhos há destruição e miséria; S1 35,2 — não temem a Deus/Bem). Entretanto, com e em parte diferentemente de Paulo, textos deuteropaulinos e pastorais fazem mais uso do termo ponerós: Ef 6,16 (escudo da fé protege contra os "dardos do Maligno"), $\mathrm{Cl}$ 1,21 (obras más/malignas), 1Tm 6,3 (falsas doutrinas tem "suspeitas malignas"), 2Tm 3,13 ("homens malignos irão de mal a pior") e 2Tm 4,18 (Deus protege de obras malignas).

Nomeando aspectos violentos da injustiça, a carta de Tiago (5,16), usando a versão grega de textos do AT (LXX) e com base em textos proféticos de Is 5,9 (final do v. 4) e Jr 12,3 (final do v.5), acusa os ricos pelo acúmulo de riquezas às custas de trabalhadores(as) empobrecidos(as), o que é considerado expressão de violência social e econômica. Neste sentido, buscando fornecer respostas às violências e perguntando pela origem de todos os males, como guerras, fome, mortes, cobiça, matança, inveja, Tg 4,1-5 conclama à amizade/parceria com Deus e não com o "mundo", indicando que os planos deste mundo são falíveis e quem neles confia demonstra conexão com o que é maligno (4,13-16). Para resistir e agir diferente, apenas é necessário achegar-se a Deus em humildade (4,10; 4,6 citando Pv 3,34 LXX) e às pessoas, em solidariedade (TAMEZ, 
1985; KRÜGER, 2005). Se a origem de todos os males está na ganância (pleonexía), sua superação está na partilha e na solidariedade (Lc 12,15.3334; 2Co 9,5; Ef 4,19; 2Pe 2,3).

Outras e igualmente vitais/mortais formas de violência são expressas pelos termos pikraíno "tratar com amargor" $(\mathrm{Cl} 3,19)$, o que, no Apocalipse, expressa causa de morte (por meio de água amarga: Ap 8,11) e indigestão (10,9.10). Esta constatação, no NT, é tão mais importante em perspectiva de gênero, porque $\mathrm{Cl} 3,19$ se dirige aos maridos e admoesta que não tratem suas esposas com "amargor", o que atualmente é entendido por violência simbólica (SINGH, 2005). Aliás, o term o grego pikría também se encontra, em suas poucas menções no NT, no famoso catálogo de vícios que conclama ao combate ao Diabo (Ef 4,31).

\section{Contextos e Realidades da Violência}

O contexto fundamental da violência ou seu exercício é a existência do ser humano em coletividade, muitas vezes na simples luta por sua sobrevivência individual ou coletiva. Este exercício da violência também se dá no contexto mais restrito, que é o da família, em suas formas variadas. Em decorrência de estruturas patriarcais em diversos sistemas político-sociais, este contexto familiar é rico em formas de violência contra mulheres, crianças e serviçais (ex. Gn 4,1-15; 37; Jz 11,30-40; 2Sm 13; Jr 11,18-23; Sl 22; Cl 3,18-4,1; Ef 5,22-6,9; 1Pe 3,1-7; 1Tim 2,8-15) (RICHTER REIMER, 2006). Abaixo vamos exemplificar mais esta questão, com análise de Juízes 19 e João 8.

O exercício da violência, contudo, pode ser incrementado quando se trata de ações em um nível mais amplo da sociedade, tais como de grupo contra grupo, de uma nação contra a outra. As guerras e batalhas para acessar e garantir a manutenção ou suprimento de bens naturais são exemplo disso ao longo de toda a história. As formas de imperialismo na Antiguidade, exercitadas de forma magistral pelos povos mesopotâmicos (assírios, babilônios, persas), são exemplos muito bem documentados. Aí, muitas vezes, se trata de ações que visam assegurar o acesso a bens considerados valiosos, tais como rios e poços d'água, produtos agrícolas, produtos provindos da 
metalurgia, artesanato, prata e ouro povo (Gn 34; Jz 12; 20-21; 2Sm 2-3; 18; 1Rs 5,27-31; 12,12-15; 2 Rs 9-10; 21,16; Is 5,8-10; Jr 5,1-9; 22,13-19; Am 2,6-8; 5,10-12; Mq 3,1-3; Sl 12; Jó 30,1-8; Pv 28,15-16; ver também Jo 4,1-30). Esses exercícios bélicos incluíam até ataques contra elementos da natureza, tais como a destruição de olivais e vinhas no entorno de cidades que não se submetiam ao domínio assírio, babilônio e persas (REIMER, 2010, p. 75-89; CARDOSO, 2016; REIMER, 2017, p. 151-176).

Neste nível mais amplo das relações sociais e políticas, há formas de contra violência, também imbuídas de violência. Assim, por exemplo, a grandiosa narrativa da libertação do povo hebreu cativo no Egito, em Ex 1-15, envolve ações violentas, que acabam resultando no acesso à liberdade rumo à terra prometida. Porém, antes da perspectiva da libertação em si, são apresentadas e legitimadas ações de violência contra integrantes do povo egípcio, autor da submissão daquele povo. As pragas do Egito expressam essa dinâmica do uso da violência para a obtenção de resultados favoráveis. Na narrativa da travessia do mar, o objetivo da libertação implica no afogamento dos perseguidores. Os cânticos de libertação, em Êxodo 15 e Juízes 5, implicam na exaltação da morte dos opressores. A releitura que o NT faz dessa grande narrativa mítica coloca o recém-nascido Jesus, junto com sua mãe Maria e seu pai José, de volta ao Egito, devido à ameaça romana, para, então, figurar um "segundo êxodo" diferenciado (Mt 2,13-23) (LUZ, 1985, p. 124-140).

O AT representa, em grande proporção, um nível de ações imperialistas ou lutas entre povos que têm como um de seus resultados o exercício do banimento, que implica em múltiplas figuras de violência com imagens de destruição física e simbólica (Js 10-12; Jz 4-16; 1Sm 4; 13-14; 15; 17; 31; 2Sm 1; 8; 10; 1Rs 20; 22; 2Rs 3-4; 6-7; 18-19; 24-25; Is 5,26-30; 28; Jr 6,1-15; 38-39; Ez 24; Am 1; Na 2-3; Ob; Sl 74; 80; 89; Lm 1-2; 3-4; Dn $2 ; 7)$. Pessoas e cidades são dedicadas à destruição. O sítio de cidades integra tais ações bélicas, tanto dos exércitos populares quanto dos oficiais (DREHER, 2002). Este nível de ações pode ser observado também no NT, expresso em representações apocalípticas contra o Império Romano (Mc 13; Ap 18; RICHARD, 1996; SCHÜSSLER FIORENZA, 1994).

Na narrativa da criação, no livro de Gênesis, também o direito de domínio (dominium terrae), enquanto atributo do exercício de poder pelos 
humanos, é expresso com a semântica de violência, utilizando os verbos radah e kabash (Gn 1,28; cf. também Gn 9,1-7; Js 11,6-9; Jz 15,4-5; Lv 1; 3-5; Nm $22,22-31 ; 1 S m$ 15,3; 2 Sm 8,4). Estes verbos, na maioria dos textos na Bíblia, apresentam reis ou governantes como seus sujeitos principais, levando a crer que em Gênesis se trata ou de uma democratização destas ações a todo gênero humano ou que os textos, em sua origem, tratavam de elementos mitológicos fundadores dos governantes (REIMER, 2010, p. 13-45). Em sua interpretação usual, as insígnias de imagem e semelhança das criaturas em relação ao criador implicam em ações de violência sobre a face da terra.

As situações de violência, envolvendo poder e dominação, também abrangem a relação da Divindade com a pessoa. Assim, o zeloso Deus bíblico é também fonte de ira e força para fazer valer a sua justiça ou a sua vontade (Gn 6-8; 19; 22; Ex 34,7; Dt 28; Jz 2,14-15; 2Sm 12; Is 1,5-9; 10,6; 47,6; 51,9; Os 11,1-9; Am 3,6; 9,1-4; Na 1; Sl 3,8; 74,13; 76,7; 90,1-12; 94; 104,7; Jó 26,12). Trata-se de exercícios de imposição de vontade, com uso e mediação de agentes humanos, especialmente funcionários especializados junto ao santuário. Também os profetas têm papelimportantenalegitimação de ações violentas derivadas do convencimento de que são portadores da mensagem e da vontade divinos. O ciclo de Elias e Eliseu, em 1Reis 17 até 2Reis 10, além de muitas narrativas com enfoques populares, indica para a vinculação entre mediação profética e recurso à violência física para a perpetração dos interesses, neste caso em termos religiosos e de dominação política. A unção de Jeú, em 2Reis 9, traz consigo violência e destruição de pessoas e comunidades, tendo como legitimação o argumento de que não adoravam exclusivamente ao Deus de Israel, Yahweh, mas praticavam formas de religião popular com marcas de diversidade religiosa. A afirmação da monolatria é acompanhada por exercícios de violência!

Especialmente marcantes são, também, as passagens no livro de Jó, no qual o personagem Jó rebelde, que é introduzido na obra a partir do capítulo 3 , critica e desvela como ele experimenta a Deus em toda a sua violência e crueldade (REIMER, 2006, p. 239-257). Para este Jó, Deus assume contornos de verdugo, justiceiro, matador ou perseguidor dos inocentes. "Tu foste cruel comigo; com a força da tua mão tu me combates. [...] Pois eu sei que me levarás à morte e à casa destinada a todo vivente" (Jó 30, 21 e 23). 
Em meio a estes contextos de violências em níveis distintos, vários são os escritos bíblicos que fazem defesa contundente das pessoas oprimidas e empobrecidas (SCHWANTES 1977; 2012). Lembramos do profeta Amós, de Isaías, Miquéias e Jeremias com denúncias e críticas circunstanciadas dos atos de dominação e violência dos mais fortes sobre os mais fracos, bem como de textos já referidos do NT (Mc 10; 13 par.; Ap 18). A perspectiva da elaboração dos textos é a partir das pessoas que sofrem as ações violentas, as quais, descritas numa gama de possibilidades, são tomadas como fundamento para o anúncio de uma iminente destruição divina, entendida como juízo no curso da história. As partes textuais que apresentam este juízo alternam, como sujeitos, o próprio Deus ou então algum poder bélico entendido e apresentado como a "mão castigadora" de Deus na história. Esta última afirmativa está mais desenvolvida no livro de Isaías, que afirma que o poder militar mais poderoso da época, a Assíria, seria a mão estendida de Deus para realizar a sua justiça, que consiste na destruição dos poderosos (Is 10,5). Porém, como refletido na música de Mercedes Sosa, a "guerra é um monstro grande que pisa forte [...]", a justiça pretendida desencadeava novamente um ciclo de dominação e violência. No todo, é importante observar que, na retórica atribuída aos profetas, verifica-se o fenômeno do empoderamento simbólico de pessoas pobres e oprimidas, tomadas como perspectiva da análise, também destinatárias preferenciais da nova situação de justiça após o anunciado juízo divino. Por este viés, o Deus zeloso e violento realiza suas ações em favor das pessoas socialmente fracas e empobrecidas na história, o que foi então formulado por Paulo, em 1Co 1,18-29, no sentido da reelaboração do estatuto político-ideológico-social inversivo: Deus escolheu as "coisas fracas/loucas/humildes/desprezadas" para desarticular e minar a violenta palavra condenatória da cruz em todas as época e situações!

Este fenômeno da violência também é abordado, normatizado e questionado nos textos bíblicos de cunho legal e ético. No AT, o foco principal está colocado na interdição geral do homicídio, conforme expresso no mandamento "não matarás" em Ex 20,13 e Dt 5,17. O sentido principal desta interdição mandamentária é a preservação da vida do outro e de sua família (CRUESEMANN, 2002). Neste mandamento, está concentrada a dimensão máxima da violência contra o outro, que pode 
assumir contornos de requintes, que hoje seriam razões de pena mais gravosa em julgamentos penais.

Esta interdição taxativa do homicídio, contudo, não era aplicada da mesma forma em partes mais casuísticas da lei hebraica. Dentro do Código da Aliança (Ex 20,22-23,19), um conjunto de leis surgido provavelmente ao final do século 8 a.C., a violência física contra o outro incluía castigos físicos contra pessoas dependentes. O senhor do escravo podia extravasar sua ira no corpo das pessoas que, por razões diversas, acabaram tendo que assumir a condição de servidão temporária ou perene. Cativos de guerras ou camponeses empobrecidos costumavam estar nesta situação (KESSLER, 2009, p. 136-167; REIMER, 2017, p. 123-150). Em meio à apresentação e análise de tais situações casuísticas, algo como precedentes jurídicos, é introduzida também a lógica da lei de talião, já conhecida a partir do contexto mesopotâmico, permitindo ao injuriado o recurso à violência ao retrucar a ação sofrida (Ex 21,12-36). Usualmente, a lei de talião, com o seu lema "olho por olho, dente por dente", tende a ser interpretada como expressão de uma sociedade violenta. No contexto dos casos apresentados, contudo, a motivação principal da lei é a proteção das pessoas, especialmente contra os ataques das pessoas socialmente mais fortes. No mesmo diapasão, contudo, naquela sociedade antiga, na qual havia o fenômeno da escravidão por dívidas ou ações de violência em decorrência de guerras, a pessoa em situação de escravidão era tratada como mercadoria, não se aplicando neste caso a retribuição mecânica segundo a lógica de talião (BENNETT, 2002). No contexto do NT, Jesus partilhava das discussões interpretativas de sua tradição legal judaica de seu tempo, sendo que os evangelhos apresentam esta sua percepção, quando, assim como outros mestres judeus, alargava a base interpretativolegal: "Ouvistes que foi dito aos antigos: Não matarás [...]. Eu, porém, vos digo [...]" (Mt 5,21-26) (LUZ, 1985).

Entre as muitas prescrições legais na Bíblia, no sentido de prevenção de violências, pode-se encontrar também normas que tratam de hospitalidade ou de asilo (Ex 21,13-14) em relação a membros da própria família ou em relação a pessoas estranhas. Na narrativa de Gênesis 18 estão indicadas formas de hospitalidade que se propunha como hábitos em relação a pessoas em trânsito ou mobilidade por razões diversas. No contexto do NT, o asilo 
e proteção eram prestados nas sinagogas e nas casas em que se reuniam comunidades cristãs (RICHTER REIMER, 1995). No AT, contudo, as casas que eram lugar de hospedagem e abrigo, às vezes, também se tornavam em palco de "prelúdio" para cenas violentas, como a que está narrada em Juízes 19, que também pressupõe tais regras de hospitalidade. Aqui é narrado um dos casos de violência mais horríveis da Bíblia.

\section{Requinte de crueldade e terror: feminicídio (Juízes 19) e ameaça de morte (João 8)}

O livro de Juízes faz parte do conjunto narrativo da Obra Historiográfica Deuteronomista (Deuteronômio até 2Reis). Por um lado, ele tenta idealizar os tempos da vida no antigo Israel sem a existência de uma estrutura estatal centralizada e, por outro, criar um contraste negativo com a época da monarquia em Israel. Trata-se de uma seleção de narrativas estilizadas que contêm crítica à existência da monarquia no antigo Israel. Um dos textos a criar este contraponto negativo à monarquia é o de Juízes 19, que narra o feminicídio da concubina de um cidadão da cidade de Belém, em Judá, pelo próprio marido/senhor ${ }^{4}$.

A narrativa é cheia de violência: ela é fato real e presente, inclusive pressuposto; ela não é questionada no livro, apenas "esparramada" em suas manifestações trágico-dramáticas. A violência, neste caso, se direciona contra a mulher, pressupondo uma estrutura patriarcal, que outorgava poderes ao pater familias de agir com poder e violência em relação aos subordinados. Por isto mesmo, faz-se necessário metodológica e hermeneuticamente esclarecer a opressão das mulheres como processo histórico (EXUM, 2012) e não como fatalidade, destino ou vontade de Deus, e evidenciar estratégias pelas quais a submissão das mulheres é introduzida e sedimentada nos e por meio dos textos sagrados. Juntamente com este procedimento, precisamos esboçar conceitos e posturas de desconstrução e reconstrução desta realidade, através de

4 Uma análise do texto em questão, em perspectiva de Direitos Humanos de mulheres, foi publicada em texto de Richter Reimer e Matos (2011). 
abordagens intertextuais e avaliação da história interpretativa de tais textos de horror e violência.

Em Jz 19 é apresentada a narrativa que envolve a história de um levita e de sua concubina que dele se aborreceu e foi infiel, deixando-o e retornando para a casa de seu pai, em Belém de Judá (19,2). O marido quis se reconciliar com ela, e foi à casa de seu sogro. A concubina e seu pai o receberam na casa e, após alguns dias, o levita quis retornar para sua cidade, levando consigo novamente a mulher. No caminho de volta, pararam num lugar chamado Gibeá, que pertencia ao território da tribo de Benjamim $(19,14)$, onde foram hospedados por um "homem velho" que parecia conhecer bem a realidade da região $(19,20)$. À noite, apareceram homens daquela cidade, designados de "filhos de Belial" (20,22), à porta daquela casa, com o intuito de extravasar seus desejos sexuais com o levita. Tudo indica tratar-se de homossexuais ou bissexuais, algo não tão incomum na Antiguidade. O hospedeiro pediu que poupassem o levita e ofereceu, em troca, sua filha virgem e a concubina para que fossem humilhadas, fazendo com elas o que desejassem $(19,24)$. O seu objetivo foi salvaguardar a vida e a honra do levita, cumprindo, portanto, com a lei da hospitalidade. Há relutância por parte dos "homens da cidade", e neste momento o levita toma frente da discussão e entrega a eles sua concubina. Então "eles a violentaram e dela abusaram a noite toda até pela manhã e então a mandaram embora" $(19,25)$. Sobrevivendo ao terror, ela conseguiu chegar à porta da casa, provavelmente moribunda, chegando a falecer, visto que não houve reação quando o marido a chamou para seguir viagem $(19,28)$.

O relato dessa concubina, por ter sido cruelmente violentada por um grupo de "homens da cidade" com o consentimento do marido, causa indignação. $\mathrm{Na}$ época, ser concubina era ser reconhecida como segunda esposa de um homem e, portanto, legalmente correto. Jz 19,2 informa que a concubina voltou para a casa de seu pai em razão de um desentendimento com o marido. As traduções não são unânimes para expressar esse desentendimento. Com a Bibel in gerechter Sprache (KEGLER, 2006, p. 452), entendemos que ela foi "infiel" ao marido e o abandonou por decisão própria! Se este "ser infiel" significa necessariamente traição sexual, adultério etc. não está explicitado no texto. As imediatas associações entre "ser infiel" e adultério/prostituição, 
quando se trata de mulheres, estão ligadas com um imaginário patriarcal e machista, para o qual autonomia e busca de liberdade e independência de mulheres se equipara com prostituição, perdição etc. Tal imaginário faz parte de relações sociais, nas quais a mulher, seu corpo e sua sexualidade pertencem ao marido, estando sob seu domínio e controle (EXUM, 2012).

Este controle e disponibilização do corpo e da sexualidade da mulher aparecem de forma escancarada em 19,24-25: o hospedeiro oferece sua filha virgem e a concubina do levita para os "homens da cidade", para que delas se aproveitem; eles, porém, reagem negativamente à proposta, porque querem o levita. Diante da insistência deles, o próprio levita pega sua concubina e a leva/arrasta para fora e a entrega a eles (v. 25). Esta cena, por meio das expressões "pegar" e "arrastar para fora", está totalmente transpassada de violência, mesmo que nas traduções não haja unanimidade em indicar quem entregou a concubina aos estupradores ${ }^{5}$. Em face ao texto, o que causa maior indignação ainda é que, enquanto a concubina era brutalmente violentada pelos homens durante toda a noite, ao voltar (sozinha, provavelmente trôpega, ensanguentada, se arrastando, já quase sem forças), ficou caída à soleira da porta da casa "até que o dia se fez claro" (v. 26), seu marido descansou durante a noite: "levantando-se o seu senhor [!] pela manhã" (v. 27)! Ele sabia o que aconteceu e mesmo assim, descansou! Ele sabia o que aconteceu, e mesmo assim a sua falaordem "Levanta-te, vamos!" (v. 28) é inequívoca quanto ao seu não-seimportar com ela e com o que ela sofreu; isto contradiz a sua intenção inicial de "falar ao coração" $(19,3)$ da esposa para que voltasse para ele!

Todas as versões bíblicas comentam a respeito da importância da lei da hospitalidade no Antigo Oriente. Uma comenta que o dono da casa estava pronto para cumprir seus deveres de hospedeiro até o heroísmo (BEJ, 2002, p. 379, nota b). Outra chega a dizer que o levita (o marido) oferece sua concubina para que o hospedeiro e sua filha sejam poupados (TEB, 1994, p. 395, nota z). Contudo, todas são unânimes em conceber que a hospitalidade era vista como direito mais sagrado do que a dignidade de

5 A Bíblia Sagrada na tradução de Almeida, 2.ed. revista e atualizada, traduz: "Então ele [o dono da casa] pegou da concubina do levita e entregou a eles fora”. 0 texto hebraico, porém, é claro em colocar esta ação entre o homem/levita e a sua concubina.

Rev. Pistis Prax., Teol. Pastor., Curitiba, v. 10, n. 1, 117-143, jan./abr. 2018 
uma mulher, uma criatura "imagem e semelhança de Deus". Em todos os casos, é preciso afirmar que constitui uma violação de direitos humanos o fato de se defender e assegurar uma lei de hospitalidade para alguns em prejuízo de outras pessoas, ou de falar sobre violências sociais, políticas e econômicas, sem observar as violências de gênero em todas as épocas e lugares! Claramente há aqui a colisão de bens jurídicos, o que requer cuidado na análise do texto.

O texto de Jz 19 termina com outra cena violenta: o "senhor" da concubina violentada e que jazia morta frente à casa do hospedeiro a leva para sua casa, onde esquarteja o seu corpo com um cutelo, em doze partes que são distribuídas entre as doze tribos de Israel. Neste contexto, contudo, o versículo 30 é significativo: ele pode expressar crítica em relação ao que aconteceu tanto com a mulher assassinada quanto com o esquartejamento. Ele faz memória desde o tempo da escravidão no Egito e afirma: Nunca se fez e se viu algo igual! Ele pode convidar para refletir e avaliar as ações sancionadas religiosamente. Seja como for, quaisquer que sejam as interpretações a partir deste versículo que pode ser entendido como contracultural na análise intratextual, fato é que, pela narrativa, este corpo da mulher que veio a óbito após estupro praticado por vários homens nem sequer recebeu um sepultamento que resguardasse a dignidade de pessoa diante da comunidade, para a qual o sepultamento significa depositar o corpo no colo da terra para que Deus o ressuscite (RICHTER REIMER, 2011). Isto nos traz à memória milhares de pessoas desaparecidas, mortas sob tortura, esquartejadas e jogadas aos quatro cantos sob ditaduras militares na América Latina até pouco tempo atrás... Seus corpos são reclamados por suas famílias, até hoje, para lhes prestar esta última homenagem.

A narrativa continua, então, em Jz 20: o mesmo levita, marido da mulher morta, reúne com a congregação do povo de Deus e conta a história em outra perspectiva (20,4-6), apresentando-se como o ameaçado da violência dos homens de Gibeá. Ele não nega o fato de terem violentado e matado sua mulher, mas silencia sobre o fato de ele e o dono da casa terem participado da trama, de terem sido partícipes e cúmplices da violência. A narrativa utiliza, agora, o esquartejamento da assassinada como motivo para que o levita incite e conclame o povo a fazer guerra para "limpar a vergonha" ocorrida. O que se segue são novas e maiores cenas de violência 
contra outros povos e, no final, mulheres e crianças da tribo de Benjamim $(20,48)$, de Jabes-Gileade $(21,11-14)$ e de Silo $(21,19-23)$ são novamente a maior parte das vítimas seja por meio do fio da espada, seja por meio de casamentos forçados com homens estrangeiros para garantir a prole deles.

Assim, destacamos que a violência contra mulheres faz parte consistente e fundamental da história narrada em Juízes e é clara demonstração da violação de direitos humanos, que perpassa a história dos povos, até hoje. Independente do fato desta obra ter sido escrita como crítica ao "tempo em que não havia rei" (Jz 21,25), há que se perguntar se a violência contra mulheres em tempos de monarquia e outras formas de governo posteriores foi suprimida da conjuntura político-cotidiana da história daquele e de outros povos, ainda hoje. Em forma de pergunta: monarquias, impérios, ditaduras, governos "democráticos" (marcados por corrupção em todas as partes do mundo) contribuíram para mudar realmente a concepção, as estratégias e ações políticas para afirmar, garantir e preservar a dignidade e os direitos humanos de mulheres?

Na história interpretativa é possível observar que textos como este de $\mathrm{Jz} 19$ revelam as tessituras e a concepção patriarcal de mundo, bem como sua mensagem explícita e subliminar às mulheres: não se comportem como a concubina que foi infiel e abandonou o seu marido, porque o castigo vem de várias maneiras! O controle patriarcal sobre a expressão da (busca de) liberdade e sobre o corpo e a sexualidade das mulheres, que fortemente se expressa por vias jurídico-legais (DETIENNE, 2011), se impôs e está profundamente sedimentado na construção de identidades pessoais e coletivas, fazendo com que este controle seja parte constitutiva do "direito dos homens", por um lado, e as agressões domésticas contra mulheres e crianças sejam consideradas como fazendo parte do "débito conjugal-familiar" que favorece o marido-pai, por outro lado. O castigo da mulher concubina que buscou reconstruir sua vida abandonando seu marido foi "desenhado" narrativamente na sua violentação e morte e, depois disto, no esquartejamento de seu corpo. Com esta última mutilação, tácita e simbolicamente a ação do marido pode apagar as marcas da violência sofrida pela mulher. Importante é perceber que o fato de a mulher ter abandonado o marido é construído narrativamente como matriz e fundamento para as violências que se seguiram contra ela 
e outras pessoas. Com isto, e com o que aconteceu com a concubina, podese querer culpabilizar as próprias mulheres que são vítimas de violência e incutir-lhes medo, para que elas permaneçam assim como agrada ao sistema patriarcal que se estende e adentra a maioria das casas e as mentalidades: obedientes, submissas e com medo.

Esta é uma estratégia central do patriarcado de todos os tempos e lugares para manter mulheres sob controle. Este medo histórico e mediatizado por meio de representações e imaginários pode paralisar mulheres ao ponto de não (mais) agirem de forma proativa e transgressora frente a situações privadas e públicas de violação de direitos humanos. É isso que também transparece e é refletido no texto de João 8,1-11.

Narrativa única nos evangelhos, muito discutida entre exegetas (BORTOLINI, 1994; SANTOS, 2011), ela apresenta uma situação que reflete questões jurídico-legais e suas interpretações para dentro de realidades vividas por muitas mulheres. Se interpretarmos o texto a partir de contextos judaicos da época de Jesus, perceberemos um equívoco, pois as interpretações bíblico-legais prejudicam representativamente esta mulher, "surpreendida em adultério" (guináika epí moichéia katalambánesthai), visto que a lei geralmente referida de Dt 22,22 prevê a "morte de ambos", homem e mulher, pressupondo seu casamento, e não apenas da mulher. Portanto, no centro da questão está a sexualidade feminina, visto que, em concepções culturais e jurídico-legais patriarcais, "adultério significa a violação do direito de propriedade/posse do marido em relação à sexualidade de sua esposa” (HABERMANN, 2012, p. 670).

Em Jo 8,1-11, apenas a mulher, acusada de adultério, é colocada "no centro"/"meio", o que indica para cena de exposição pública e julgamento. Portanto, do que se trataria, visto que o homem está ausente? Na memórianarrativa joanina, quem a apresentou foram escribas e fariseus, quando Jesus ensinava no templo, em Jerusalém. Ele foi confrontado com esta situação complexa e colocado diante da citação oral da referida lei de Moisés ("Esta mulher foi pega em flagrante adultério. Na lei, Moisés nos ordenou apedrejar estas. O que tu dizes?” - Jo 8,5). Ora, Dt 22,22 e Lv 20,10 não 
preveem esta pena, que é destinada a pessoas casadas, pegas em flagrante adultério, para a qual mestres judeus sugeriam o estrangulamento ${ }^{6}$.

Em se tratando de apedrejamento, como mencionado em Jo 8,5 (lithádzein), de que situação poderia se tratar? Esta pena é prevista em Dt 22,23-29, contudo não para mulheres casadas, mas para "moça virgem, desposada", portanto, noiva, prometida em casamento, como no caso de Maria (Mt 1,18.20; Lc 1,27.34)! Este detalhe dá uma reviravolta na história interpretativa deste texto. Detienne (2011, p. 64) ilustra a situação desesperadora da jovem virgem que, em ameaça de ou situação de estupro, não consegue gritar, ou não o suficiente para ser ouvida, e mesmo assim ela seria acusada de adultério, para o que ambos (!!) deveriam ser mortos. Vasculhando documentos, encontramos um texto de interpretação judaica de Dt 22,23-24, que, contudo, apenas prevê a morte por apedrejamento do homem (!) que teve relações sexuais com uma jovem virgem, noiva (Sanh 7,4.9 apud STRACK e BILLERBECK, 1989, p. 521), mas não detalha a pena da jovem mulher. Nada, pois, parece se aplicar a este texto joanino, quando interpretado a partir de tradições judaicas.

Com Wengst (2000) entendemos que a narrativa não retroprojeta o contexto de adultérios e estupros no tempo de Jesus e de seus companheiros judeus. Isto talvez não seja acaso, até porque não há nenhuma prova de que tais penas alguma vez tenham sido executadas. Pelo contrário, mestres e rabinos, também em caso de tais delitos, que, de acordo com a Torá seriam passíveis de pena de morte, elaboravam barreiras interpretativas (como visto acima) num processo de acusação, de tal forma que a execução se tornava impossível ${ }^{7}$. Trata-se, na nossa perspectiva e análise, de uma narrativa magistral, que não ignora as tradições judaicas, mas que, na virada dos séculos I-II, busca criar possibilidades de reconciliação no contexto de uma igreja cristã que buscava viver o Reino de Deus/dos céus,

6 Assim ensinava Rabi Joschijja (140d.C., Sanh 11,1.6) (apud STRACK e BILLERBECK, 1989, p. 520) e seus colegas durante séculos, que discutiam esta lei: “Reflita: uma pena de morte, cujo modo não é definido na Torá, não se pode aplicar para dificultar a morte, mas para torná-la menos dolorosa [...], portanto, por meio de entrangulamento".

7 Ver uma série de citações de Talmud e Midrasch em Wengst (2000, p. 304).

Rev. Pistis Prax., Teol. Pastor., Curitiba, v. 10, n. 1, 117-143, jan./abr. 2018 
que não é "deste mundo" ${ }^{\text {, }}$ mas que não estava sabendo lidar com casos de adultério e de estupros que continuavam a existir também dentro dela, portanto, no mundo! Recorrer à memória de Jesus, neste contexto e caso específicos da igreja, é propor mecanismos e possibilidades de reconciliação interpessoais e comunitárias, sem acarretar mais danos e violência às mulheres: não exclusão/morte, mas acolhida, paciência, ouvir sabiamente, incluir a comunidade na reflexão com base na humildade do reconhecimento de que "não há um justo sequer" e que todos(as) carecem de perdão, bem como do convite por perseverar na busca de uma vida liberta de dominação, também do pecado (Jo 8,11).

\section{Considerações finais}

Em meio a contextos nos quais a violência em suas diversas formas fazia parte da realidade do cotidiano, os textos sagrados se utilizam da linguagem referente a estes fenômenos para tecer suas mensagens. Acima, destacamos vários contextos e situações. No entanto, cabe, para finalizar, destacar também que a Bíblia é perpassada por propostas que buscam interromper o círculo da violência. Uma delas se encontra em Miquéias 4, 1-7 (com texto paralelo em Isaías 2,1-4). A proposta de transformar espadas em arados e lanças em podadeiras tem sido recepcionada em muitas situações em que a crítica à corrida e ao aparato bélico é convertida em proposta ou perspectiva de paz ou, pelo menos, de um mundo sem guerras.

Também a cruz como "a” expressão da violência a que Jesus e tantas outras pessoas foram submetidas, é ressignificada por meio da ressurreição, tornando-se representação e superação de todas as formas de violências, questionando-as, tirando-lhes a legitimidade. Junto com isso projetam as perspectivas de ações de cura da violência: humildade, justiça, sabedoria, perseverança e fortalecimento na fé (Tg 5,8-11). Em contextos de guerra, Jesus propõe o envio de uma "embaixada, pedindo condições de paz" (Lc 14,32).

8 Sobre as possíveis construções de relações heterotópicas na comunidade joanina, ver Guerra (2015), com "estado da questão" acerca do evangelho de João. 


\section{Referências}

BENNETT, H. V. Injustice made legal: Deuteronomic law and the plight of widow, strangers and orphans in ancient Israel. Grand Rapids; Cambridge: Eerdmans Publisching Company, 2002.

BÍBLIA DE ESTUDO JERUSALÉM [BEJ]. São Paulo: Paulus, 2002.

BORTOLINI, J. Como ler o Evangelho de João: o caminho da vida. 1.ed. São Paulo: Paulus, 1994.

BROER, I. Exousía: Freiheit [...] Macht. In: BALZ, H.; SCHNEIDER, G. In: Exegetisches Wörterbuch zum Neuen Testament. 2. ed. Stuttgart; Berlin; Köln: Kohlhammer, 1992. p. 23-29.

CARDOSO, N. P. Onde estiver o seu Tesouro ali também o seu Coração: Mineração, Tecnologia e Economia em Jó 28. Caminhos, Goiânia, v. 14, n. 1, p. 97-111, 2016.

CROATTO, J. SEVERINO. As linguagens da experiência religiosa: uma introdução à fenomenologia da religião. Trad. Carlos Maria Vásquez Gutiérrez. São Paulo: Paulinas, 2001.

CRUESEMANN, F. A Torá: teologia e história social da lei no Antigo Testamento. Trad. Haroldo Reimer. Petrópolis: Vozes, 2002.

DETIENNE, C. V. R. Em desmemória dela: violência jurídica e simbólica contra a mulher na Bíblia Hebraica. In: RICHTER REIMER, I. (org.). In: Direitos Humanos: enfoques bíblicos, teológicos e filosóficos. São Leopoldo: Oikos; Goiânia: Ed. da PUC Goiás, 2011. p. 61-72.

DREHER, C. A. A constituição dos exércitos no Reino de Israel. São Paulo: Paulus; São Leopoldo: CEBI, 2002.

EXUM, J. C. Judges: Encoded Messages to Women. In: SCHOTTROFF, L.; WACKER, M.-T. (Eds.). Feminist Biblical Interpretation: a Compendium of Critical Commentary on the Books of the Bible and Related Literature. Michigan/ Cambridge: Grand Rapids; Eerdmans Publishing Co., 2012. p. 112-127.

GUERRA, D. D. O Reino de Deus e o mundo dos homens: em busca da heterotopia joanina. Dissertação (Mestrado em Ciências da Religião) — PUC Goiás, Goiânia, 2015. 
GÜNTHER, W. Pecado. In: COENEN, L.; BROWN, C. Dicionário Internacional de Teologia do Novo Testamento. 2. ed. São Paulo: Vida Nova, 2000. p. 1598-1602.

HABERMANN, R. Gospel of John: spaces for Women. In: SCHOTTROFF, L.; WACKER, M.-T. (Eds.). Feminist Biblical Interpretation: a Compendium of Critical Commentary on the Books of the Bible and Related Literature. Michigan/ Cambridge: Grand Rapids; Eerdmans Publishing Co., 2012. p. 662-679.

HORSLEY, R. A. Jesus e o Império: o reino de Deus e a nova desordem mundial. São Paulo: Paulus, 2004.

KESSLER, R. História social do antigo Testamento. Trad. Haroldo Reimer. São Paulo: Paulinas, 2009.

KRÜGER, R. Pobres y ricos en la epístola de Santiago: el desafío de un Cristianismo profético. Buenos Aires: LUMEN/ISEDET, 2005.

KEGLER, J. Über die Zeit der Richterinnen und Richter. In: BAIL, U. et al. Bibel in gerechter Sprache. 1. Aufl. Gütersloh: Gütersloher Verlagshaus, 2006. p. 416-457. [Introdução e tradução de Juízes].

LUZ, U. Das Evangelium nach Matthäus. Zürich; Einsiedeln; Köln: Benziger; Neukirchen-Vluyn: Neukirchener, 1985.

REIMER, H. Bíblia e ecologia. São Paulo: Reflexão, 2010.

REIMER, H. O antigo Israel. História, textos e representações. São Paulo: Fonte Editorial; Anápolis: Ed. da UEG, 2017.

REIMER, H. Pobre sujeito. Sobre o direito dos empobrecidos no livro de Jó. In: DREHER, C. A. et al. Profecia e esperança: um tributo a Milton Schwantes. São Leopoldo: Oikos, 2006. p. 239-257.

RICHARD, P. Apocalipse: reconstrução da esperança. Petrópolis: Vozes, 1996.

RICHTER REIMER, I; MATOS, K. Silencioso desespero: violência e silêncio contra a mulher em casa e na Bíblia. In: RICHTER REIMER, I (org.). Direitos Humanos: enfoques bíblicos, teológicos e filosóficos. São Leopoldo: Oikos; Goiânia: Ed.da PUC Goiás, 2011. p. 73-90. 
REIMER, H.; REIMER, I. R.

RICHTER REIMER, I. Women in the Acts of the Apostles: a feminist liberation Perspective. Minneapolis: Fortress Press, 1995.

RICHTER REIMER, I. O Belo, as Feras e o Novo Tempo. São Paulo: Vozes; São Leopoldo: CEBI, 2000.

RICHTER REIMER, I. Patriarcado e economia política: o jeito romano de organizar a casa. In: RICHTER REIMER, I. (org.). Economia no Mundo Bíblico: enfoques sociais, históricos e teológicos. São Leopoldo: CEBI; Sinodal, 2006. p. 72-97.

RICHTER REIMER, I. Ananias e Safira nas origens do Cristianismo e suas interpretações: reler e reconstruir Atos 5,1-11. São Leopoldo: Oikos, 2011.

SANTOS, J. R. dos. Religião e violência contra a mulher: diferentes olhares. In: RICHTER REIMER, I. (org.). Direitos Humanos: enfoques bíblicos, teológicos e filosóficos. São Leopoldo: Oikos; Goiânia: Ed. da PUC Goiás, 2011. p. 91-104.

STEGEMANN, W. Jesus e seu tempo. São Leopoldo: Sinodal/EST, 2012.

SCHWANTES, M. Das Recht der Armen. Frankfurt: Peter Lang, 1977.

SCHWANTES, M. O direito dos pobres. São Bernardo do Campo: Editeo; São Leopoldo: Oikos, 2012.

SCHÜSSLER FIORENZA, E. Das Buch der Offenbarung: Vision einer gerechten Welt. Stuttgart; Berlin; Köln: Kohlhammer, 1994.

SINGH, P. (org.). As igrejas dizem NÃO à violência contra a mulher: plano de ação para as igrejas. Genebra: Federação Luterana Mundial; São Leopoldo: Sinodal, 2005.

STRACK, H.; BILLERBECK, P. Das Evangelium nach Markus, Lukas und Johannes und die Apostelgeschichte erläutert aus Talmud und Midrasch. 9. Ed. München: C.H.Beck'sche Verlagsbuchhandlung, 1989.

TAMEZ, E. Santiago: Lectura latinoamericana de la epístola. San José/Costa Rica: DEI, 1985. (Colección aportes).

BÍBLIA TRADUÇÃO ECUMÊNICA (TEB). São Paulo: Loyola, 1994. 
WENGST, K. Pax Romana: pretensão e realidade. São Paulo: Paulinas, 1981.

WENGST, K. Das Johannes-evangelium. v.2. Stuttgart; Berlin; Köln: Kohlhammer, 2000.

Recebido: 17/07/2017

Received: 07/17/2017

Aprovado: 15/11/2017

Approved: 11/15/2017 